\title{
多目的最適化手法を用いた構造物の動的問題における実験同定
}

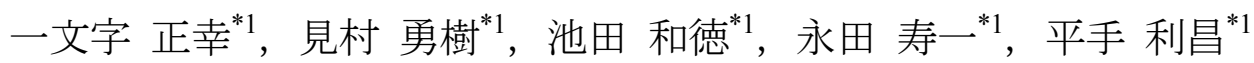
平井 匡平 ${ }^{* 2}$, 平野 俊夫 ${ }^{* 1}$, 淵本 尞 $^{* 3}$, 塩飽 宣貴 $^{* 4}$, 荒川 雅生 ${ }^{* 5}$

\section{Experimental identification on natural frequency of structure using multi-objective optimizing method}

\author{
Masayuki ICHIMONJI ${ }^{* 1}$, Yuki MIMURA* ${ }^{* 1}$, Kazunori IKEDA*1 ${ }^{*}$ Toshikazu NAGATA*1, \\ Toshiaki HIRATE $^{* 1}$, Kyohei HIRAI ${ }^{* 2}$, Toshio HIRANO*1 ${ }^{*}$, Ryo FUCHIMOTO ${ }^{* 3}$, \\ Takanobu SHIWAKU ${ }^{* 4}$ and Masao ARAKAWA ${ }^{* 5}$ \\ ${ }^{{ }_{1},{ }^{* 2}}$ Power and Industrial Systems Research and Development Center, TOSHIBA Corporation \\ 2-4 Suehiro-cho, Tsurumi-ku, Yokohama 230-0045, Japan \\ ${ }^{*}$ Keihin Product Operations, TOSHIBA Corporation \\ 2-4 Suehiro-cho, Tsurumi-ku, Yokohama 230-0045, Japan \\ ${ }^{*} 4,{ }^{5}$ Department of Electronics and Information Engineering, Kagawa University \\ 2217-20 Hayashi-cho, Takamatsu 761-0396, Japan
}

Received: 13 February 2017; Revised: 8 June 2017; Accepted: 10 September 2017

\begin{abstract}
Dynamic FEM analysis is valid for designing rotating machinery to reduce its vibration problem when we may ensure enough accuracy of the analysis. Surrogate multiple objective optimization method is one of the most effective methods for structural identification improving the FEM analysis model of a structure to adjust the natural frequency analysis results to the experimental results. In this study the structural identification method is applied to stator end-windings of a turbine generator to determine the Young's modulus of the principal components on the FE model minimizing the analysis errors of the natural frequencies of the 2-lobe and 4-lobe circular modes to the corresponding experimental results. The accurate FE model of the end-windings is obtained by this method.
\end{abstract}

Key words : Structural identification, Natural frequency analysis, Surrogate multiple objective optimization method, Electronic rotating machnery, Stator end windings

\section{1. 緒言}

回転機械の設計に当たっては低振動化をはかって振動問題を未然に回避することが，製品の信頼性確保の上で 重要な設計項目の一つとなっている. 有限要素法を用いた振動解析による課題抽出と低振動化対策は製品開発で 欠かせないが，その前提として解析精度の確保が振動解析に要求される。しかしながら，製品の形状，運用形態 に即した複雑で大規模な構造物に有限要素法を用いた振動解析では解析結果が測定結果に対して大きな乘離を生 じる場合が見られる。これは構造物の支持条件に加えて構成部材の動的な材料特性が静的な材料試験で得られた 結果とは異なることに起因している（篠原他，2004）。個々の部材の物性值について単独で材料試験により評価を 行っているが，静的試験によるものが主で必ずしも動的な特性が得られているとは限らない．また，単体試験で は製品に組み込まれた状態での試験ができない部材も多数存在する. そのため, 解析精度の高い正確な解析モデ

No.17-00056 [DOI:10.1299/transjsme.17-00056], J-STAGE Advance Publication date : 19 September, 2017

本論文は，第26回設計工学・システム部門講演会 講演論文集(2016), No.1303の掲載内容に基づいた論文である.

*1正員，（株）東芝 電力・社会システム技術開発センター（テ230-0045 神奈川県横浜市鶴見区末広町 2-4）

*2 (株) 東芝 電力・社会システム技術開発センター

*3 (株) 東芝 京浜事業所

*4 香川大学 工学部（干761-0396 香川県高松市林町 2217-20)

*5 正員, 香川大学 工学部

E-mail of corresponding author: masayuki.ichimonji@toshiba.co.jp 
Ichimonji, Mimura, Ikeda, Nagata, Hirate, Hirai, Hirano, Fuchimoto, Shiwaku and Arakawa, Transactions of the JSME (in Japanese), Vol.83, No.853 (2017)

ルを構築するに当たり, 解析モデルにおける支持条件や構成部材の物性值を修正して解析結果を実測值に合わせ 込むモデルアップデート作業に多大な労力と作業時間を費やしているのが現状である. 実際の現象を正確にシミ ユレーション可能な解析モデルが短期間で構築できないことは低振動設計の妨げであるばかりか, トラブル発生 時における迅速な原因究明，対策立案，対策効果検証を行う上でも重大な障害となっている．モデルアップデー トのリードタイム短縮は製品開発，問題解決の両面で急務の課題と考える.

モデルアップデートの方策の一つとして構造解析に最適化手法を組み合わせた実験同定が考えられる. しかし ながら, 単一解しかもたない静的解析とは異なって振動問題の場合には複数存在する固有振動モードを同時に合 せ込まなくてはならないので, この方法を採用するには最適化手法の多目的化が課題となる. 従来の最適化手法 では単一の目的関数を対象とするものが主流であったから，何らかの方法で複数ある目的関数をスカラー化する 必要がある. 代表的なのが固有振動数の実測值に対する誤差の二乗平均值を目的関数とするものである (Saito et al., 2015).この方法では解析誤差の二乗平均が全体的に最小化されるが，個々の固有振動数の解析誤差が実測值 に近づく保証は得られない，精度向上を希望する固有振動モードが必ずしも改善されず，ともすると非現実的な 解に収束することが生じた. このような状況において, サロゲート多目的満足化手法が実用化されるに至った (中 山他, 2007).この手法は目的関数を近似することより演算の高速化をはかるサロゲート最適化(逐次近似最適化) を目的関数間のトレードオフが容易な多目的満足化トレードオフ法に適用したものである. サロゲート多目的満 足化手法を振動解析と組み合わせて用いれば, 構造解析の未確定な材料定数を設計变数とし, 個々の固有振動数 の実測值に対する解析誤差を目的関数とする多目的最適化問題を解くことによって, 複数の固有振動数の精度を 同時に満足する材料定数を同定することが可能となる. 本手法は従来の最適化手法に比べて目的関数間のトレー ドオフが容易なので, 希望する固有振動モードについて固有振動数の解析精度を選択的に向上できる利点を有し ている.

これまで, 筆者らは比較的単純な形状のリング構造物を対象としてサロゲート多目的満足化手法と有限要素法 振動解析とを組み合わせて, 複数の固有振動数を同時に合わせ込む実験同定問題に取り組み, 短時間で構造物の 固有振動解析精度を向上できることを確認している（見村他，2015）。さらに，回転電気機械の固定子鉄心の円環 固有振動モードの実験同定問題に前記の手法を拡張して製品レベルで本手法の妥当性を検証した（Shiwaku et al., 2016). 本研究では, 構造がさらに複雑でかつ大規模なタービン発電固定子コイルエンドを解析対象として, 電気 機械特有の電磁力加振に対する離調対策で重要な円環振動モード固有振動数に着目し, その解析誤差最小化問題 にサロゲート多目的満足化手法を適用して実験同定手法への実用性を検討する.

\section{2. 解析方法}

\section{$2 \cdot 1$ サロゲート多目的満足化}

一般に, 最適化の定式化は, $\min f(\boldsymbol{x})$

Subject to

$g_{j}(\boldsymbol{x}) \leq g_{j^{a}}$

$x_{i} \leq x_{i} \leq x_{i}{ }^{H}$

と表わされる.ここに，

$\boldsymbol{x}=\left\{x_{1}, x_{2}, \ldots, x_{N}\right\}^{\mathrm{T}}$

は設計変数, $f(\boldsymbol{x})$ は目的関数, $g_{j}(\boldsymbol{x})$ は制約条件である. また, $N$ は設計変数の数， $x_{i}{ }^{L}, x_{i}{ }^{l}$ はそれぞれ設計変数 $x_{i}$ の下限值と上限值， $g^{a}$ は制約条件の制限值である. 上記に対して多目的最適化では目的関数が複数になる;

$$
\min F(x)=\left\{f_{1}(x), f_{2}(x), \ldots, f_{L}(x)\right\}^{\mathrm{T}}
$$

たたし, $L$ は目的関数の数である.このままでは目的関数がスカラーではないので解を得ることができないため, スカラー化の方策が必要となる. これまでの最適化問題では, 個々の目的関数 $f_{i}$ に重み $w_{i}$ を付けた加重和を新た な目的関数とする方法が一般的であった. すなわち 


$$
\min \Phi(\boldsymbol{x})=w_{1} f_{1}(\boldsymbol{x})+w_{2} f_{2}(\boldsymbol{x})+\cdots+w_{L} f_{L}(\boldsymbol{x})
$$

しかしながら，式(4)による方法では非凸な目的関数空間に対して最適解を抽出することはできない. そこで本研 究では満足化トレードオフ法を採用する. 満足化トレードオフ法では式(5)に示すようにスカラー化にティビチェ フノルムを利用し，理想点と希求水準を導入する.

$$
\min \Phi(x)=\max \left(w_{k} \frac{f_{k}-a s p_{k}}{a_{s p_{k}}-\text { ideal }_{k}}\right)
$$

ここに, ideal $k: k$ 番目の目的関数の理想点, $a s p_{k}: k$ 番目の目的関数の希求水準である.

多目的満足化トレードオフ法では, 目的関数の理想点と希求水準を調節することで, 目的関数間のトレードオ フが可能となり，設計者が望む最適解を得易くなる.

一方, サロゲート最適化手法 (逐次近似最適化手法) が実用化されている（中山他, 2007). サロゲート最適化 手法では最適化の過程において目的関数や制約条件をRBF（放射基底関数）による関数近似を行うことで広域の 設計空間を効率的に探索できる. RBF は, 入力層 (素子数 $n$ ), 中間層 (素子数 $m$ ), 出力層 (素子数 $l$ ) の 3 層か らなる階層型ニューラルネットワークの一種であって, 中間素子の出力関数として基底関数を用いて, 出力素子 からの出力は中間素子の出力の加重和で定義する.

$$
h(\boldsymbol{x}, \boldsymbol{c}, \boldsymbol{r})=\sum_{i=1}^{m} w_{1} \cdot \operatorname{Exp}\left(\sum_{j=1}^{m} \frac{\left(x_{j}-c_{j}\right)^{2}}{r_{j}^{2}}\right)
$$

式(6)では基底関数として一般的に用いられているガウス分布関数を用いている. $c_{j}$ は基底関数を配置する中心を 意味し， $r_{j}$ がその基底関数の半径となる．これに重み $w_{i}$ を決めることで応答関数を得ることができる． $\boldsymbol{x}_{i}$ にお ける教師值 $\boldsymbol{y}_{i}=\left\{y_{i 1}, y_{i 2}, \ldots, y_{i p}\right\}$ に対してネットワークのエネルギー；

$$
E_{i}=\sum_{i=1}^{p}\left(y_{i j}-h_{i}\left(x_{j}\right)\right)^{2}+\sum_{k=1}^{m} \lambda_{i j} w_{i k}^{2}
$$

が求められる. RBFネットワークの学習は式(7)のエネルギーの最小化をはかることで,

$$
\boldsymbol{w}_{k}=\boldsymbol{A}^{-1} \boldsymbol{H}^{T} \boldsymbol{y}_{k}
$$

を得る.ここに，

$$
\boldsymbol{A}^{-1}=\left(\boldsymbol{H}^{T} \boldsymbol{H}+\boldsymbol{\Lambda}\right)^{-1}
$$

$$
\boldsymbol{H}=\left[\begin{array}{cccc}
h\left(x_{1}, c_{1}, r_{1}\right) & h\left(x_{2}, c_{2}, r_{2}\right) & \cdots & h\left(x_{1}, c_{m}, r_{m}\right) \\
h\left(x_{2}, c_{1}, r_{1}\right) & h\left(x_{2}, c_{2}, r_{2}\right) & \cdots & h\left(x_{2}, c_{m}, r_{m}\right) \\
\vdots & \vdots & \ddots & \vdots \\
h\left(x_{p}, c_{1}, r_{1}\right) & h\left(x_{p}, c_{2}, r_{2}\right) & \cdots & h\left(x_{p}, c_{m}, r_{m}\right)
\end{array}\right]
$$

$$
\boldsymbol{\Lambda}=\left[\begin{array}{cccc}
\lambda_{1} & 0 & \cdots & 0 \\
0 & \lambda_{2} & \cdots & 0 \\
\vdots & \vdots & \ddots & \vdots \\
0 & 0 & \cdots & \lambda_{m}
\end{array}\right]
$$

である. 式(8)は逆行列の演算であることから自己抑制項Aにより Aの正則性が保証されるため演算の信頼性が非 常に高い. また, RBFによる関数近似はガウス分布関数を基底関数とすることで裙野における誤差拡大がなく, 応答曲面を作るのに必要なデータ点も設計変数の数に左右されないという利点がある. 


\section{$2 \cdot 2$ 複数の固有振動数を目的関数とした構造同定}

対象とする構造物が有する複数の固有振動モードについて, 構造物の加振試験から得られた伝達関数に実験モ 一ド解析を適用寸ることによって固有振動モードベクトル $\boldsymbol{u}_{1}, \boldsymbol{u}_{2}, \ldots, \boldsymbol{u}_{L}$ とこれに対応寸る固有振動数 $f_{n 1}, f_{n 2}$, $\ldots, f_{n L}$ を求める.

一方, 対象構造物の有限要素法解析モデルを作成して固有振動解析を実施し, 固有振動数 $f^{\prime}{ }_{n 1}, f^{\prime}{ }_{n 2}, \ldots, f_{n M}^{\prime}$ と固 有振動モードベクトル $\boldsymbol{v}_{1}, \boldsymbol{v}_{2}, \ldots, \boldsymbol{v}_{M}$ を求めれば, 固有振動数と固有振動モードベクトルは有限要素法解析モデル に与えられる形状寸法，材料定数などの設計変数 $\boldsymbol{x}=\left\{x_{1}, x_{2}, \ldots, x_{N}\right\}^{\mathrm{T}}$ の関数となる.

ここで，固有振動数の実測值に対する解析值の誤差絶対值 ;

$$
f_{k}(\boldsymbol{x})=\frac{\left|f_{n k}^{\prime}-f_{n k}\right|}{f_{n k}}
$$

を目的関数とする多目的最適化問題を考え, 解法として上記のサロゲート多目的満足化手法を適用することによ って解析対象にある固有振動数の実測值に対寸る解析值の誤差の最小化をはかる．さらに，実測と解析の固有振 動モードの対応付けには式(13)に示す MAC 值を用いる（Miroslav et al., 2012）.

$$
\operatorname{MAC}_{i j}=\frac{\boldsymbol{v}_{i}^{T} \boldsymbol{u}_{j}}{\left(\boldsymbol{v}_{i}^{T} \boldsymbol{v}_{i}\right)\left(\boldsymbol{u}_{j}^{T} \boldsymbol{u}_{j}\right)}
$$

$\mathrm{MAC}_{i j}$ 值は 0 から 1 の值を取り, 解析固有振動モード $\boldsymbol{v}_{i}$ と実測固有振動モード $\boldsymbol{u}_{j}$ との相関を表す指標である. な お，ここで採用した手法の詳細については文献（Shiwaku et al., 2016）を参照されたい.

\section{3. 固定子コイルエンドへの適用}

\section{$3 \cdot 1$ 解析対象}

図 1 は対象とするタービン発電機のコイルエンドの固有振動解析モデルである. 固定子コイルは固定子鉄心の 内部ではスロット内に納められているので強固に固定されているが，コイルエンド部では固定子スロットから突 き出した片持ちはりの構造であって，固定子スロット内と比較すると剛性が低くなっている．一方，コイルには 導体を流れる電流によってコイル相互間に非常に強力な電磁力が作用するのでコイルエンドでは振動を発生し易 い(一文字他, 2010). 有限要素法の定式化に基づく構造解析モデルは, コイルエンドの固有振動解析およびその 結果を利用する応答解析の根幹をなすもので，その解析精度は製品の信頼性確保の上できわめて重要である. 電 磁力の分布形状を考慮すると, とりわけ固有振動解析におけるコイルエンドの 2 直径節円環振動モードと 4 直径 節円環固有振動モードが応答解析において重要で, これらのモードの固有振動解析精度が応答解析の精度にも強 い影響を与える.

\section{$3 \cdot 2$ 設計変数}

設計変数は表 1 に示すようにコイルエンドを構成する主要な 14 部材のヤング率とし, 静的材料試験結果を基準 に正規化して取り扱う．組立によって動的なヤング率の值は基準值から変化する可能性が考えられるため，各部 材の組立状況に即した設計変数の上下限值が設定されている. 最適化は基準値を初期值とする.

\section{$3 \cdot 3$ 目的関数}

実験同定の目標となる実験モード解析結果を図 2 に示す。上述の理由から 2 直径節および 4 直径節円環固有振 動モードに着目する．両モードにはそれぞれ共役根が存在するので，合計 4 モードが実験同定の対象となる. 目 的関数は式(12)に示寸各モードの解析誤差と式(13)に示寸各モードの MAC 值を用いる．ただし，MAC 值は実測 モード自体に対するものではなく, 設計変数基準值による解析で得られた固有モードに代える. すなわち, 設計 変数基準值による固有振動解析結果から前記 $4 つ の$ 実測モードに対する MAC 值の高い固有モードを抽出する (図 3 参照)．最適化の過程では図 3 の解析によるモードを実測モードに代えて式(13)の基準モード $\boldsymbol{u}_{j} に$ 用いる. 目的 関数を目標值，希求水準とともに表 2 に整理する. 
Ichimonji, Mimura, Ikeda, Nagata, Hirate, Hirai, Hirano, Fuchimoto, Shiwaku and Arakawa, Transactions of the JSME (in Japanese), Vol.83, No.853 (2017)

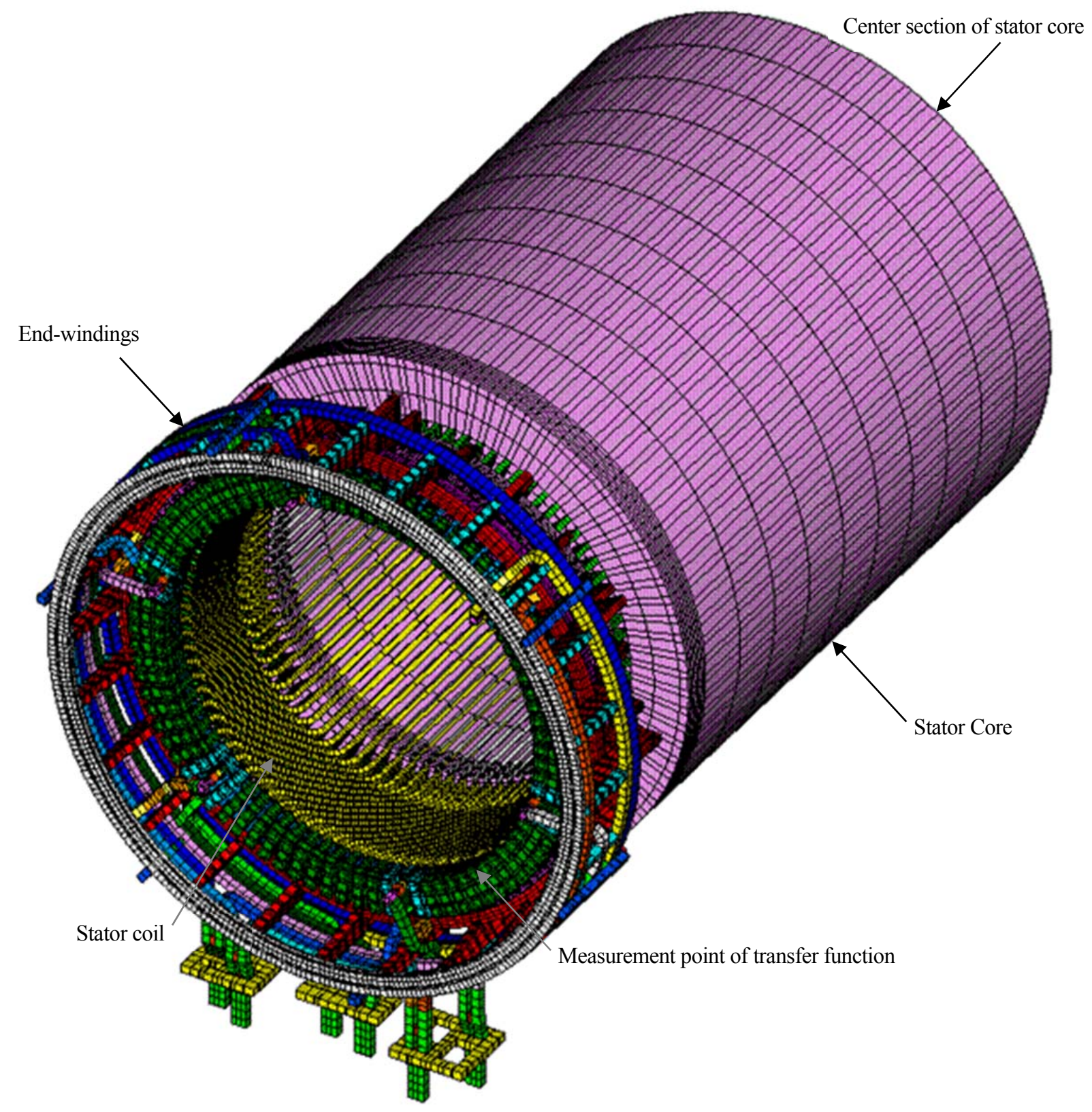

Fig.1 FE analysis model of end-windings and stator core of turbine generator. This figure shows a finite element model of end-windings and stator core of a turbine generator for natural frequency analysis. Almost components of the structure are divided to solid elements. Stator coils are inserted into the stator core and turn on the end of the stator core. The stator core behind of the center section is eliminated and the symmetric boundary condition is set on the section. 


\section{$3 \cdot 4$ 実験同定}

実験同定は，表 1 に示すコイルエンドの主要部材のヤング率を設計変数に， 2 直径節および 4 直径節固有振動 モードの実測固有振動数に対する固有振動解析結果の誤差を目的関数とする最適化問題（誤差最小化問題）をサ ロゲート多目的満足化により解くことになる．最適化の過程において設計変数の変化に伴って着目固有振動モ一 ドの固有振動数に順番の入れ替わりが生じることからモードの追尾が必要となる. 本解析では $3 \cdot 3$ で記述したよ うに目的関数に MAC を追加することによって着目するモードを抽出している.

上記の手法によりコイルエンド解析モデルにおけるヤング率の実験同定を行った. 実験同定の前後で目的関数 の変化を比較したものが表 3 である.

Table 1 Design variables, their range and optimized results.

\begin{tabular}{c|c|c|c}
\hline \hline \multirow{2}{*}{ Material ID } & \multicolumn{2}{|c|}{ Normalized variable range } & \multirow{2}{*}{ Result } \\
\cline { 2 - 3 } & Minimum value & Maximum value & \\
\hline 1 & 0.8 & 1.1 & 1.07 \\
\hline 2 & 0.5 & 1.1 & 0.891 \\
\hline 3 & 0.8 & 1.1 & 0.896 \\
\hline 4 & 0.5 & 1.1 & 0.821 \\
\hline 5 & 0.2 & 1.1 & 0.339 \\
\hline 6 & 0.2 & 1.1 & 0.820 \\
\hline 7 & 0.2 & 1.1 & 0.924 \\
\hline 8 & 0.5 & 1.1 & 0.756 \\
\hline 9 & 0.5 & 1.1 & 1.10 \\
\hline 10 & 0.5 & 1.1 & 0.838 \\
\hline 11 & 0.2 & 1.1 & 0.985 \\
\hline 12 & 0.2 & 1.1 & 0.244 \\
\hline 13 & 0.2 & 1.1 & 1.10 \\
\hline 14 & 0.2 & 1.1 & 0.672 \\
\hline
\end{tabular}

Table 2 Objective function.

\begin{tabular}{c|l|c|c}
\hline \hline ID & \multicolumn{1}{|c|}{ Item } & Ideal pointer & Aspiration level \\
\hline 1 & Error of 2-lobe mode (lower) & $0.0 \%$ & $1.0 \%$ \\
\hline 2 & Error of 2-lobe mode (higher) & $0.0 \%$ & $1.0 \%$ \\
\hline 3 & Error of 4-lobe mode (lower) & $0.0 \%$ & $1.0 \%$ \\
\hline 4 & Error of 4-lobe mode (higher) & $0.0 \%$ & $1.0 \%$ \\
\hline 5 & MAC value of 2-lobe mode (lower) & 1.0 & 0.9 \\
\hline 6 & MAC value of 2-lobe mode (higher) & 1.0 & 0.9 \\
\hline 7 & MAC value of 4-lobe mode (lower) & 1.0 & 0.9 \\
\hline 8 & MAC value of 4-lobe mode (higher) & 1.0 & 0.9 \\
\hline
\end{tabular}




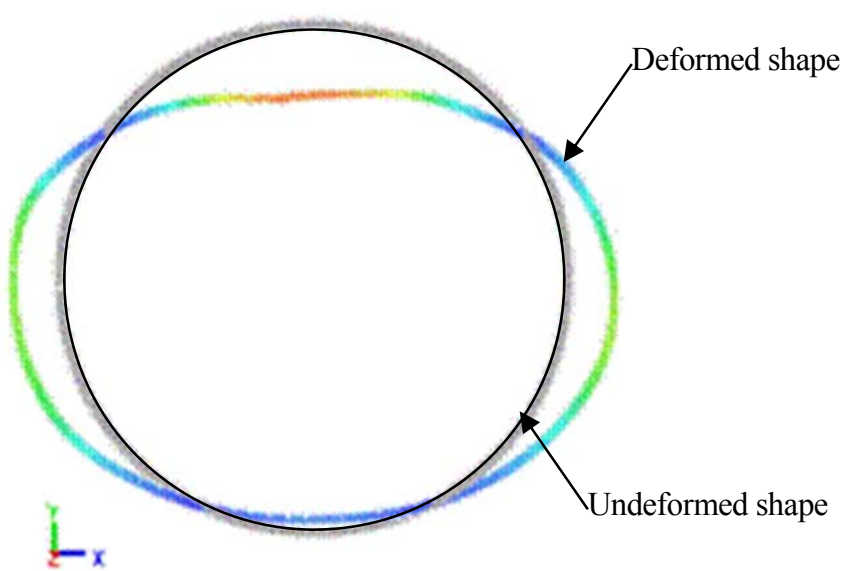

(a) 2-lobe mode (lower)

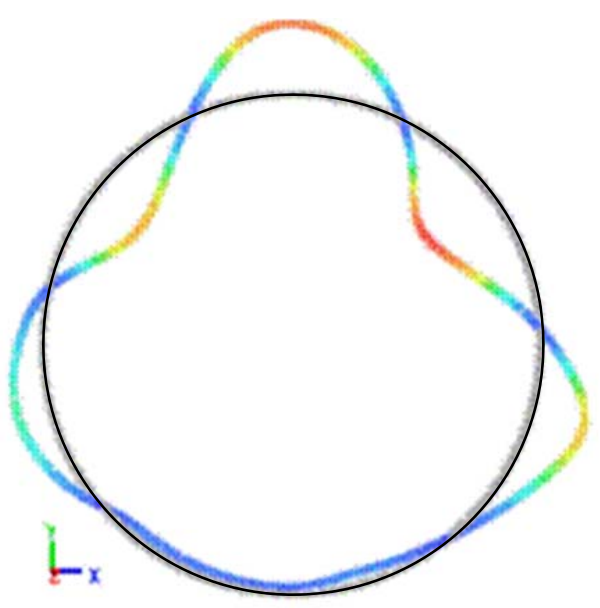

(c) 4-lobe mode (lower)

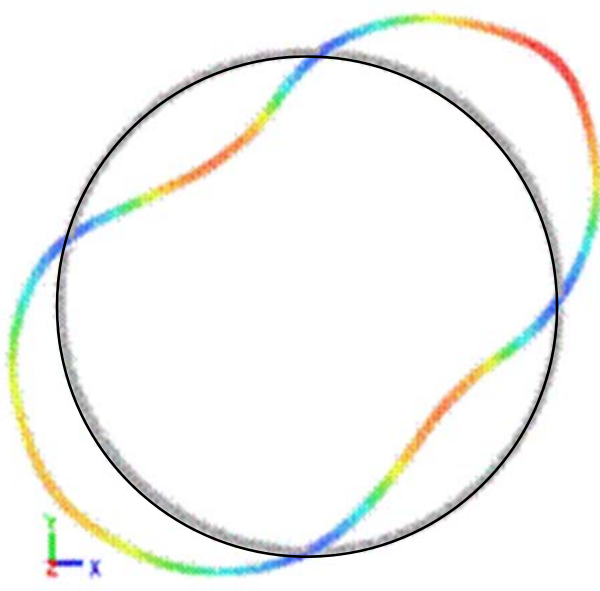

(b) 2-lobe mode (higher)

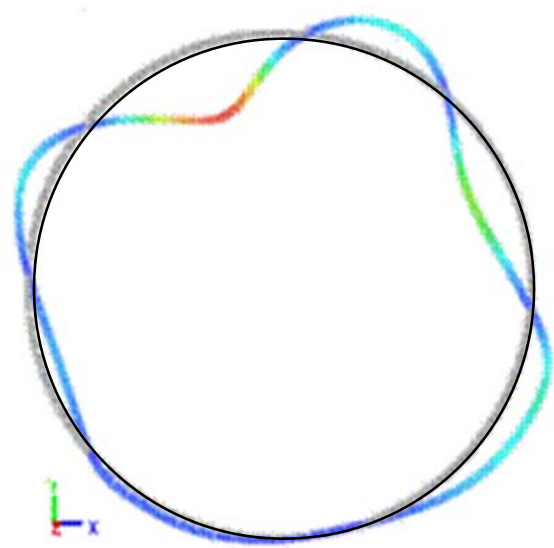

(d) 4-lobe mode (higher)

Fig.2 Measured natural modes of end-windings of turbine generator (2-lobes modes and 4-lobes modes). These modes are estimated by experimental modal analysis from transfer functions measured on the end points of the all bars of the end-windings. 2-lobes modes and 4-lobes modes are extracted here.

Table 3 Analysis errors of natural frequency and MAC value of end-windings updated by the optimizing.

\begin{tabular}{c|c|c|c|c}
\hline \multirow{2}{*}{ Mode } & \multicolumn{2}{|c|}{ Initial value } & \multicolumn{2}{c}{ Result } \\
\cline { 2 - 5 } & Error \% & MAC & Error \% & MAC \\
\hline (a) 2-lobe mode (lower) & -2.32 & 1.00 & -3.36 & 0.999 \\
\hline (b) 2-lobe mode (higher) & 1.72 & 1.00 & 1.61 & 0.997 \\
\hline (c) 4-lobe mode (lower) & -9.01 & 1.00 & 0.98 & 0.940 \\
\hline (d) 4-lobe mode (higher) & 7.33 & 1.00 & 0.86 & 0.970 \\
\hline
\end{tabular}




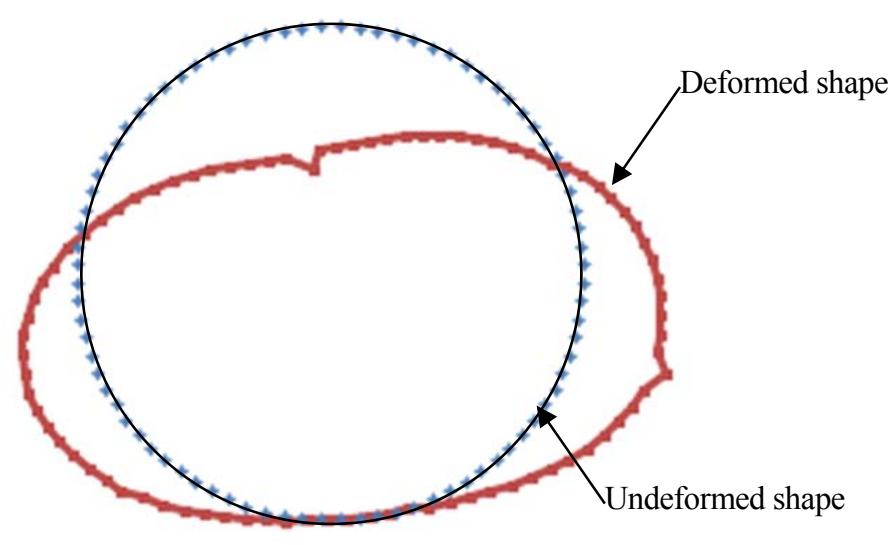

(a) 2-lobe mode (lower)

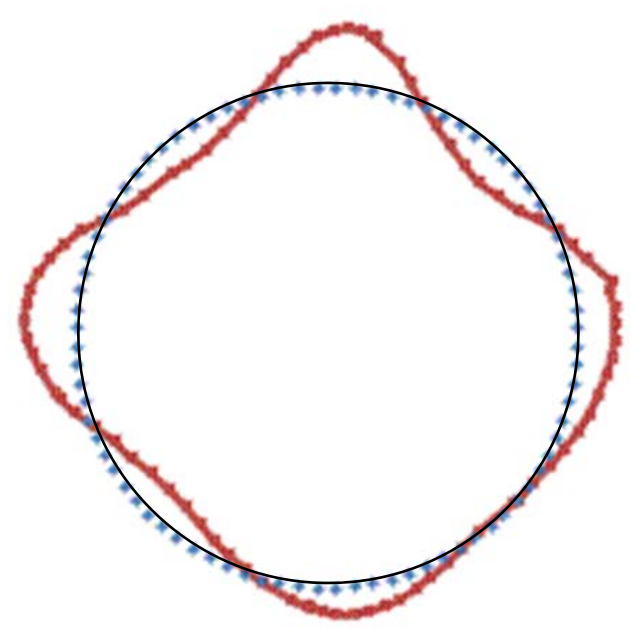

(c) 4-lobe mode (lower)

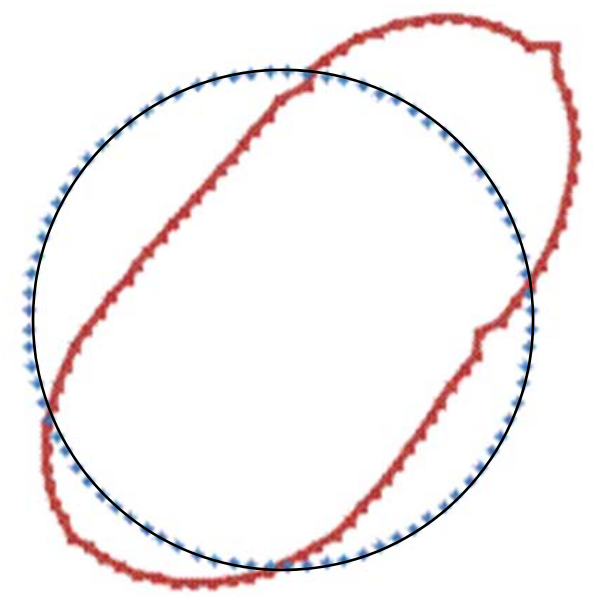

(b) 2-lobe mode (higher)

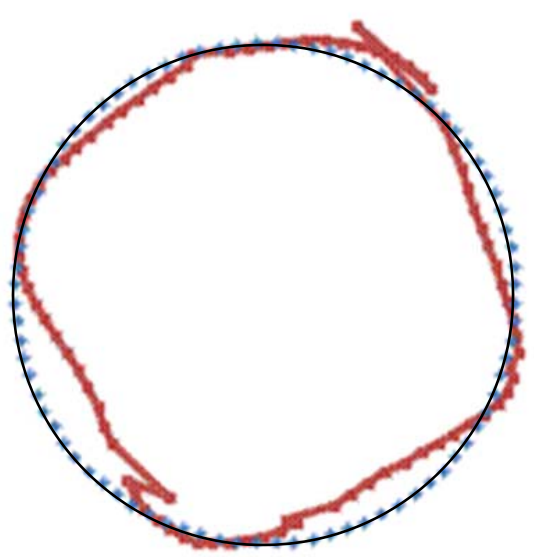

(d) 4-lobe mode (higher)

Fig.3 Calculated natural modes of end-windings of turbine generator (2-lobes modes and 4-lobes modes). 2-lobes modes and 4-lobes modes of the end-windings of the generator are calculated by FE analysis using the model shown in Fig.1. The nodes of coils corresponding to the measurement points are plotted. These modes are selected by MAC values to the measured modes shown on Fig. 2.

\section{4. 考 察}

\section{$4 \cdot 1$ 同定結果}

表 3 示寸同定結果を見ると, 着目する 2 直径節および 4 直径節円環振動モードの固有振動解析誤差についてサ ロゲート多目的満足化手法による合せ込み前後で比較すれば，実測固有振動数に対する有限要素法固有振動解析 結果の誤差は初期值に対して実験同定後は全般に縮小されていることがわかる．とりわけ4 直径節モードで顕著 な改善が見られている.

表 1 には設計変数の実験同定後の結果を併記してあるが，これを見ると一部の部材（部材番号 5 と 12）の值が それぞれ $0.339,0.244$ と突出して低下しているものの，これ以外の部材については大きな変化は生じていない. これらの部材はコイルエンド全体の固有振動数に対する構造的な寄与が高いものと推定されている. コイルエン ドは図 1 に示すようにたい几ん複雑な構造をなしており, 構成部材の材料の動的特性が製造, 組立過程で静的特 
Ichimonji, Mimura, Ikeda, Nagata, Hirate, Hirai, Hirano, Fuchimoto, Shiwaku and Arakawa, Transactions of the JSME (in Japanese), Vol.83, No.853 (2017)

性から変化する可能性があり，コイルエンドに組み込んだ状態での材料特性を評価することが困難であった．実 験同定を実施することによって実際の状態に即したヤング率が特定できたものと考える.

ただし，低次 2 直径節モードでは固有振動解析誤差が初期段階で-2.32\%であったものが実験同定後には-3.36\% となっており，誤差の絶対值がわずかながら拡大している．これは満足化の過程でトレードオフが生じたことに よるもので，サロゲート多目的満足化の特性を表していると言える. 従来の加重和法などではすべての目的関数 の一律的な改善をはからうとするので，とも寸るとあり得ない設計変数に収束してしまうことが見られた，サロ ゲート多目的満足化では希求水準の達成を優先させるので, 目的関数間でトレードオフがなされて全体的な目的 関数の最適化がなされたものと思われる.

このように，サロゲート多目的満足化を有限要素法固有振動解析モデルの実測との合せ込む実験同定に適用す ることは解析精度向上の上で非常に有効である．複数の固有振動モードを同時に合わせ込めること，比較的少な い試行回数でほぼ満足できる解が得られることは, 加重和法などこれまでの最適化手法と比較して有利である. これにより有限要素法解析モデルの合せ込み作業時間を大幅に短縮寸ることが可能となり，製品の共振回避対策 の迅速化ひいては信頼性向上に大きく貢献するものと期待される．以上からサロゲート多目的満足化手法による 実験同定の妥当性が確認できた.

Table 4 MAC values of calculation and experimentation

\begin{tabular}{c|c|c|c|c}
\hline \multirow{2}{*}{ Mode } & \multicolumn{2}{|c|}{ Initial value } & \multicolumn{2}{c}{ Result } \\
\cline { 2 - 5 } & Calculation & Experimentation & Calculation & Experimentation \\
\hline (a) 2-lobe mode (lower) & 1.00 & 0.668 & 0.999 & 0.600 \\
\hline (b) 2-lobe mode (higher) & 1.00 & 0.541 & 0.997 & 0.515 \\
\hline (c) 4-lobe mode (lower) & 1.00 & 0.200 & 0.940 & 0.228 \\
\hline (d) 4-lobe mode (higher) & 1.00 & 0.353 & 0.970 & 0.225 \\
\hline
\end{tabular}

\section{4・2 MAC值によるモード追尾}

実験同定の過程では着目した 2 直径節，4 直径節円環固有振動モードの固有振動数を的確に抽出することが重 要である. 単純な問題では材料定数を変化させても固有振動モードの順番に入れ替りが生じないこともあるが, コイルエンドのような大規模で複雑な構造物を対象とする場合には，材料定数が変化すると固有振動モードの順 番に入れ替わりが生じることがある.例えば, 高次4直径節円振動モードは初期段階には15次モードであったが, 実験同定後には 19 次モードに移行していた. すなわち, 対象モードの実測結果と最適化の過程で繰り返し計算さ れる解析結果をその都度対応付けておかなくては正確な最適解が得られない. 本解析で採用した MAC 值の利用 はその対策として有用である.

しかしながら，実測固有振動モードを基準とすることは実用的でないことが判明した．表 4 は表 3 の結果に対 して実測モードを基準とする MAC と初期解析における解析モードを基準とする MAC 值を比較したものである. 後者は実験同定の前後でも 1 に近い值を保っているが，前者はそれに比べるとかなり值が小さくなっている. 特 に 4 直径節モードについては 0.5 以下になっていて，他のモードの MAC と区別できない場合があった．これは 実測モードが解析モードと比較して変形形状が不明確であることに起因していると考える．本手法では解析モー ドを基準とする MAC 值を採用した。この方法は初期段階で実測モードを基準とする MACを参考にして実測モ ードと対応付けを解析作業者が経験的に行わなくてはならないが，対応付けが適切であればモードの誤認を大幅 に低減できる. 


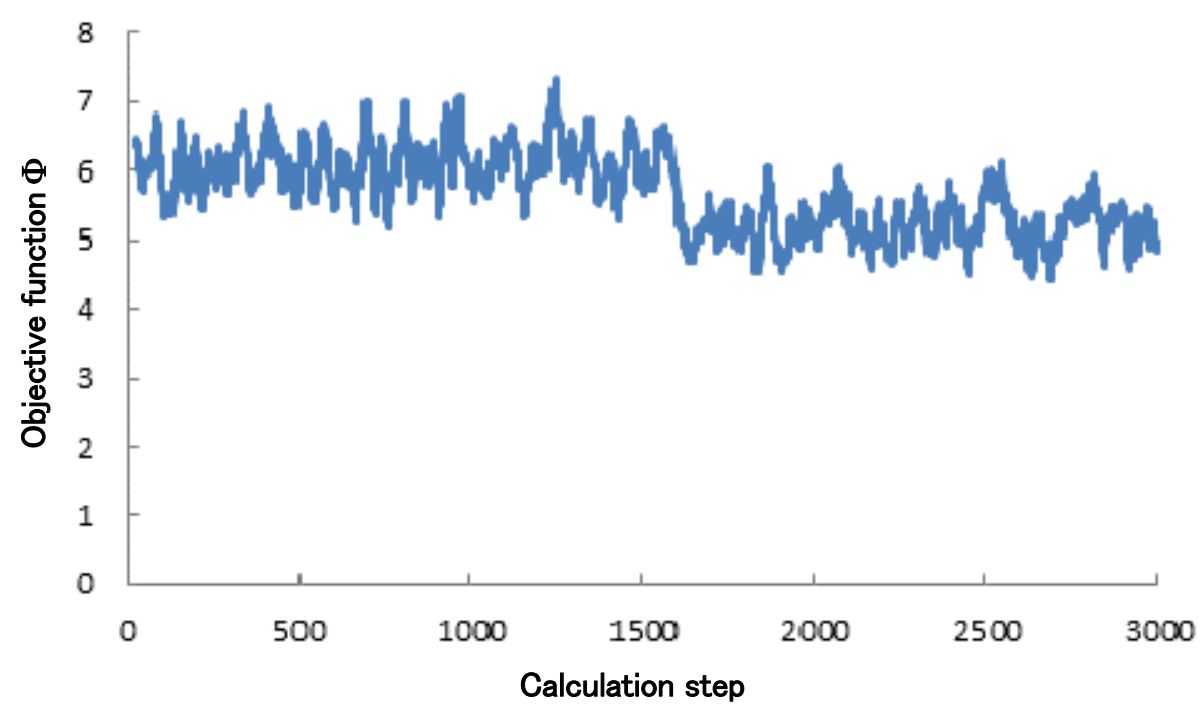

Fig.4 History of the scaled factor to the calculation steps is shown in this graph. The scaled factor decreased little by little according to the calculation steps with the alternation. The sudden decrease of the scaled factor can be recognized after about 1500 steps.

\section{$4 \cdot 3$ 多目的サロゲート満足化法の演算過程}

本解析におけるサロゲート多目的満足化の計算過程における収束状況を図 4 に示す。これは式(5)における 最適化演算回数に対する変化を表わしたものである. 最適化開始後, Фは変動を繰り返しながら漸減しているが, 計算回数 1500 回目付近において顕著な減少が認められる. その後は再び変動しつつ緩やかな減少する傾向を示し ている. 変化が大きい箇所で大局的な最適解に到達したものと推測される. 3000 回程度の計算回数で十分な解析 精度を有する有限要素解析モデルが同定された. 従来のような試行錯誤的なモデルアップデート作業に比べると， 自動化されたサロゲート多目的満足化による実験同定手法の導入によりモデルアップデートの作業時間を大幅に 短縮することができた.

なお，多目的満足化法と振動解析を結びつけた実験同定手法の手順を付録に示す.

\section{5. 結 言}

タービン発電機固定子コイルエンドを対象として, 実験モード解析で測定された2直径節，4直径節円環固有振 動モードに対応する実測固有振動数に対する固有振動解析結果との誤差を目的関数に, 主要な構成部材のヤング 率を設計変数にそれぞれ設定した最適化問題に対してサロゲート多目的満足化手法を適用し, 固有振動測定結果 に対する有限要素法解析モデルの合せ込む実験同定を実施して以下の知見が得られた.

（1）実験同定によって実測固有振動数に対する有限要素法固有振動解析結果の誤差は, 全般的に初期値と比較 すると大幅に縮小され，最適化の効果が確認された.

(2) 低次 2 直径節円環振動モードについてわずかながら誤差の絶対值が大きくなった. これは目的関数のトレー ドオフによるものである.

(3) 目的関数に対象モードの実測と解析間のMAC值を加えることにより最適化過程で的確なモード追尾が可 能となり精度の向上につながった.

（4）採用したサロゲート多目的満足化手法はコイルエンドのような複雑で大規模な構造物に対しても妥当な 解が得られたことから，実験同定の手法として実用性が高い. 


\section{文献}

一文字正幸，上田隆司，藤田真史，郡司雄一郎，村田大輔，片山仁，鉄心振動による強制振動を考慮したタービ ン発電機固定子コイルエンドの電磁振動解析, 第 22 回電磁力関連シンポジウム講演論文集 (2010), pp.280-283.

見村勇樹，一文字正幸，平井匡平，永田寿一，平手利昌，荒川雅生，多目的最適化を用いた固有振動解析モデル の同定，日本機械学会 2015 年度年次大会講演論文集(2015), J1030205.

Miroslav, P., Binda, M. and Harčarik, T., Modal assurance criterion, Procedia Engineering Vol.48 (2012), pp.543-548.

中山弘隆, 岡部達哉, 荒川雅生, 尹禮分, 多目的最適化と工学設計一しなやかシステム工学アプローチ, 現代図 書(2007), pp.21-28, 160-161.

Saito, A., Nishikawa, S., Yamasaki, S., Fujita, K., Kawamoto, A., Kuroishi, M. and Nakai, H., Elastic moduli identification method for orthotropic structures based on vibration data, the 11th World Congress on Structural and Multidisciplinary Optimization (2015), ID1208.

篠原主勲, 坂本茂, 江島英博, 後藤文彦, タービン発電機ステータコイルエンドの固有振動特性, 日本機械学会 論文集 C 編，Vol.70, No.962 (2004), pp.941-948.

Shiwaku, N., Arakawa, M., Mimura, Y., Nagata, T., Hirate, T. and Kamijo, Y., Elastic moduli identification method using the convolute RBF and surrogate optimization, Proceedings of Asian Congress of Structural and Multidisciplinary Optimization 2016(2016), 3C1-4.

\section{References}

Ichimonji, M., Ueda, T., Fujita, M., Gunji, Y., Murata, D. and Katayama, H., Dynamic response analysis of end-windings of turbine generator for electromagnetic forces considering excitation from stator core, Proceedings of the 22th Symposium on Electromagnetics and Dynamics (2010), pp.280-283 (in Japanese).

Mimura, Y., Ichimonji, M., Hirai, K., Nagata, T., Hirate, T. and Arakawa, M., Identification of dynamic structural model Using multiple objective optimization method, Proceedings of Mechanical Engineering Congress, 2015 Japan (2015), J1030205 (in Japanese).

Miroslav, P., Binda, M. and Harčarik, T., Modal assurance criterion, Procedia Engineering Vol.48 (2012), pp.543-548.

Nakayama, H., Okabe, T., Arakawa, M. and Yun, Y. B., Multidisciplinary optimization and engineering design (2007), pp.21-28, 160-161, Gendai tosho (in Japanese).

Saito, A., Nishikawa, S., Yamasaki, S., Fujita, K., Kawamoto, A., Kuroishi, M. and Nakai, H., Elastic moduli identification method for orthotropic structures based on vibration data, the 11th World Congress on Structural and Multidisciplinary Optimization (2015), ID1208.

Shinohara, K., Sakamoto, S., Ejima, H. and Goto, F., Natural vibration characteristics of a stator end of a turbine generator, Transactions of the Japan Society of Mechanical Engineers, Series C, Vol.70, No.692 (2004), pp.941-948 (in Japanese).

Shiwaku, N., Arakawa, M., Mimura, Y., Nagata, T., Hirate, T. and Kamijo, Y., Elastic moduli identification method using the convolute RBF and surrogate optimization, Proceedings of Asian Congress of Structural and Multidisciplinary Optimization 2016(2016), 3C1-4.

\section{付 録}

本研究で用いた多目的満足化法と振動解析を結びつけた実験同定手法の手順を図 A に示す. 
Ichimonji, Mimura, Ikeda, Nagata, Hirate, Hirai, Hirano, Fuchimoto, Shiwaku and Arakawa, Transactions of the JSME (in Japanese), Vol.83, No.853 (2017)

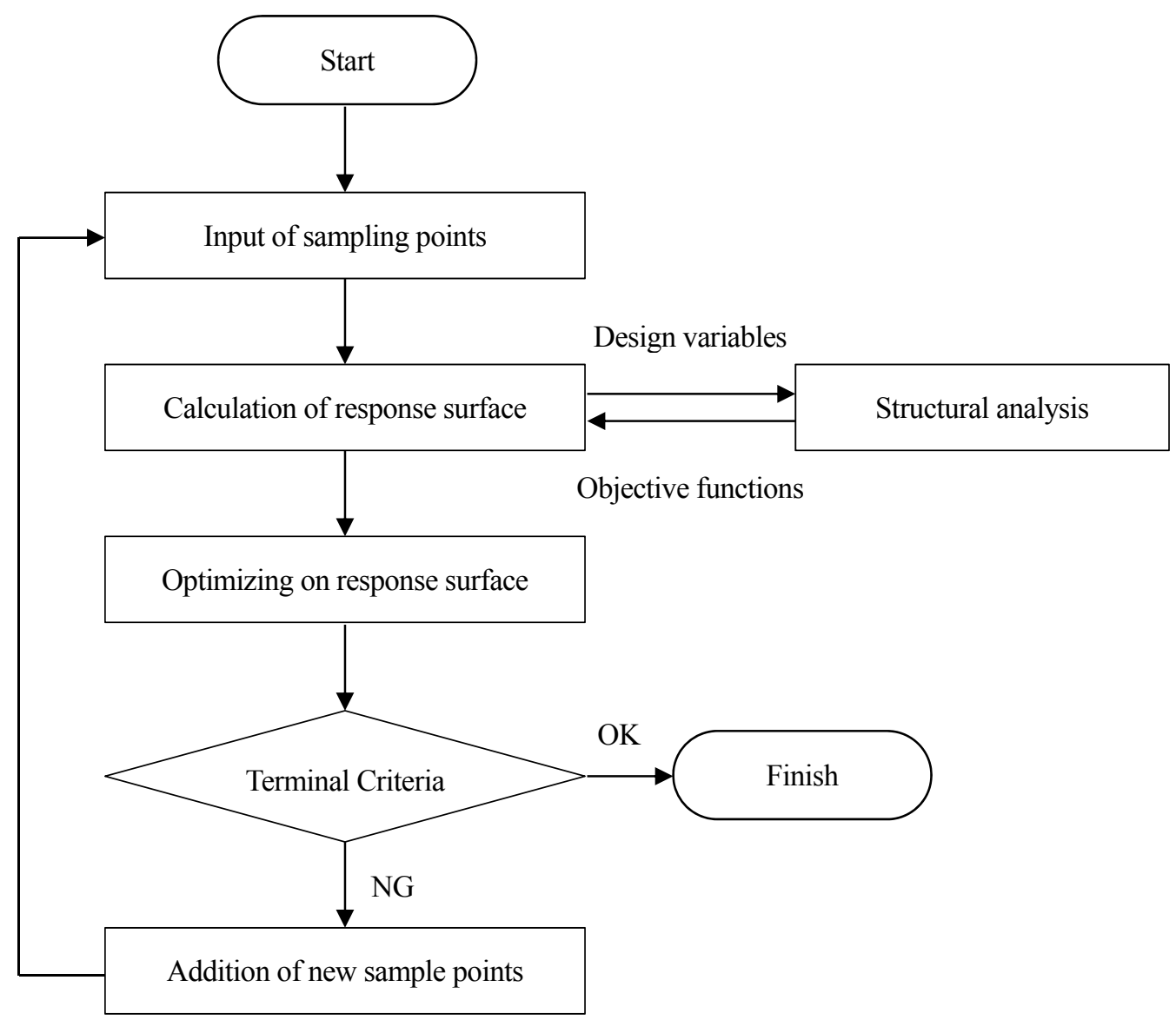

Fig. A The general procedure of the experimental identification connecting satisficing trade-off method and structural analysis is shown. 